\title{
Cognitive Personality Traits and Technical Knowledge of Young People in Lithuania
}

\author{
Ala KOVIERIENE் \\ ŠiauliaiUniversity \\ Vilnius str. 141, LT-76001 Šiauliai, Lithuania \\ e-mail:al.ko@tf.su.lt
}

Received: June 2008

\begin{abstract}
The review of research works presented in the paper leads to the supposition that scientists abroad usually analyze the components of technical knowledge in relationship with personal traits while in Lithuania no research of this kind has been carried out yet. The author of the article comes to the conclusion that there is a quite insignificant correlation between the results of the test on applied technical knowledge and results of two tests on basic comprehension-knowledge (curriculum and terminology). Essential correlation coefficients of theoretical technical knowledge with the results of the tests on basic comprehension-knowledge (curriculum and terminology) have been established. This leads to maintain that cognitive personality traits make a considerable influence on theoretical technical knowledge while applied technical knowledge is affected only to some extent.
\end{abstract}

Keywords: applied technical knowledge, theoretical technical knowledge, cognitive personal traits, basic comprehension-knowledge.

\section{Introduction}

The assessment of comprehension-knowledge in engineering should be based on valid and reliable methodological and psychometric tests (Anastazi and Urbina, 2001; Bitinas, 1998; Kooper, 2000; Jovaiša and Vaitkevičius, 1987; Merkys, 1999) The assessment of comprehension-knowledge in engineering could be significant for those who have chosen the career connected with engineering and technology, for teachers of technical professions; it could be applied in professional counselling centres, while employing the staff for production industries, etc. The assessment of comprehension-knowledge in engineering would cause problems without scientific operationalization of comprehensionknowledge in engineering, as a psychometric construct based on psychometric constructs that are analogical to comprehension-knowledge in engineering constructs and are recognized throughout the world. Individual's cognitive traits, defined as comprehensionknowledge in engineering, must be measured, using valid and reliable diagnostic instruments, which are created or adapted in the corresponding country. Assessment of the relationships of cognitive variables with comprehension-knowledge in engineering is presented in this work. 
Researchers (Sodiya et al., 2007) presented the theory about individual differences of lead to variability in knowledge, skills, and work habits that mediate effects of personality and cognitive ability on job performance. Another group of scientists (Motowidlo et al., 2008) analyzed personality characteristics on knowledge, skill, and performance of personality traits in software engineering. The correlation of individual's cognitive traits and his/her technical knowledge has not been properly studied in the scientific world, moreover, in Lithuania there were no research of this problem at all, as there were no diagnostic instruments of both general and technical education. Today in Lithuania there are such researches (Blinstrubas, 2002; Kovieriene, 2004). The existing (or not-existing) connection between the mentioned notions may be defined having methodologically proved instruments.

475 young people were surveyed. They were the students of Šiauliai University Technological Faculty (both full-time and part-time studies). The others were from colleges (technical and business), tertiary technical schools, comprehensive schools (main, secondary and evening), gymnasiums and vocational schools. The age of the respondents varied from 14 to 25 years old. $65.3 \%$ of them were male and $34.7 \%$ were female. $44.21 \%$ of the research respondents have chosen technical education (the students of Śiauliai University Technological Faculty, tertiary technical school, vocational technical schools), while $55.79 \%$ have not yet decided on their careers or have chosen non-technical education (from main, secondary, secondary adult schools or gymnasiums, as well as business college students).

\section{Instruments for Measuring the Technical Knowledge and Cognitive Personality Traits}

One of the selected instruments for solving the problem put forward is a test developed in Germany and adapted - the test of applied technical knowledge (Lienert, 1958). All 32 tasks with optional answers reflect practical-technical problems and can be solved visually, 6 tasks out of which failed to correspond to Lithuanian population and, therefore, were withdrawn upon the determination of negative intercorrelation. The following validity factors for this test have been identified: purposeful combination and meaningful supplementation ability, and logical thinking. Its objectivity, reliability, external and internal validity have been checked.

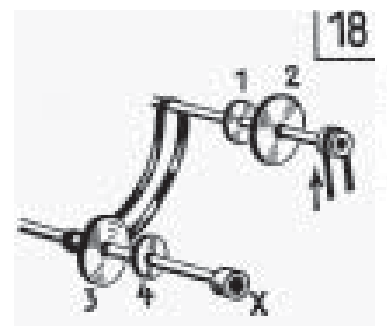

Which pulleys have to be interconnected. so that axis $X$ swirls with the highest sposd?

Answers : $\mathrm{A}-1$ and $\mathrm{J}$

$\mathrm{B}-2$ and 4

C -1 and 4

D -2 and 3

Fig. 1. Figure of Task 18 of the applied technical knowledge test. 


\begin{tabular}{|c|l|l|l|}
\hline CLUTCH & 1 & & $\begin{array}{l}\text { 6. The device replacing any kind of energy into the } \\
\text { mechanical energy. }\end{array}$ \\
\cline { 1 - 1 } ENGINE & 6 & & 7. The mechanism for air or gas compression. \\
\hline
\end{tabular}

Fig. 2. Cell of task of the theoretical technical knowledge test.

The problem of Task 18 is that the movement of each element influences the movement of another element, thus the piece-meal movement analysis strategy has been applied.

The second test applied for measurement of technical knowledge is the test on theoretical technical knowledge. This test has been created with reference to technical knowledge treated as psychometric construct concept, considering the peculiarities of test structuring and testing procedure, and additionally consulting the experts. The format of theoretical technical knowledge test is "to find adequate" (Ingekamp, 1991). Respondents should find a true answer and its number point in the square blank, answers are more than lines.

Items are checked and analysis carried out by establishing item difficulty coefficient $\mathrm{P}$ and item-total correlation $(r / i t t)$. Results of item analysis of the test on theoretical technical knowledge are in accordance with validity standards. After multiple factor analysis, statements of the test on theoretical technical knowledge, in accordance with the rules of logical connection, were consolidated into five factors, the statistical characteristics of which satisfy methodological requirements.

On the basis of the results obtained, it is possible to confirm that tests on applied and theoretical technical knowledge are valid in respect of the assessment construct of Lithuanian teenagers' and young people's comprehension-knowledge in engineering.

Two more tests used for the assessment of basic knowledge were the curriculum and terminology tests the author of which is Blinstrubas (2002). The format of these tests is the same as formats of the test of the theoretical technical knowledge. Comprehension-

Table 1

Factor analysis of the theoretical technical knowledge test results $(\mathrm{KMO}=0.70$, percentage of variance explained $-46.59 \%$ )

\begin{tabular}{lcccc}
\hline Name of factor & $\begin{array}{c}\text { Number of } \\
\text { primary } \\
\text { variables }\end{array}$ & $\begin{array}{c}\text { Item-total } \\
\text { correlation, } \\
r / \text { itt }\end{array}$ & $\begin{array}{c}\text { The factor loading } \\
\text { of test item, } \\
L\end{array}$ & Cronbach $\alpha$ \\
\hline $\begin{array}{l}\text { Internal and external structure of an } \\
\text { appliance }\end{array}$ & 6 & 0.67 & 0.861 & 0.68 \\
$\begin{array}{l}\text { Facts of technical development his- } \\
\text { tory }\end{array}$ & 4 & 0.49 & 0.734 \\
$\begin{array}{l}\text { Knowledge in the theory of engi- } \\
\text { neering }\end{array}$ & 2 & 0.46 & 0.681 \\
$\begin{array}{l}\text { Domestic appliances } \\
\text { Sequence of introducing profes- } \\
\text { sions and appliances }\end{array}$ & 2 & 0.34 & 0.546 \\
\hline
\end{tabular}




\begin{tabular}{|r|l|l|l|}
\hline RESPIRATORY & 3 & & 1. Processing and intake a material from food \\
\cline { 1 - 1 } DIGESTIVE & 1 & & 2. Produce hormone cells. \\
\hline
\end{tabular}

Fig. 3. Cell of task of the comprehension-knowledge curriculum test (biology).

\begin{tabular}{|r|l|l|l|}
\hline BESTSELLER & 3 & & 2. Moon researcher \\
COSMOPOLITAN & 5 & & 3. The most marketable book \\
\hline
\end{tabular}

Fig. 4. Cell of task of the comprehension-knowledge terminology test.

knowledge curriculum test is related to the subjects taught at school, it consists of 11 units (Biology, History, Chemistry, etc.).

The basis of the comprehension-knowledge terminology test is the international scientific and cultural terms, which are not included in the curriculum of the secondary school.

Both tests have been statistically conducted and their indexes correspond to the theory of tests.

\section{The Results of Ccoherence Assessment of the Technical Knowledge and Cognitive Personality Traits}

The influence of cognitive variables on technical knowledge was assessed by applying correlation and multiple regression analyses.

It was stayed that the results of boys' and girls' applied technical knowledge are little connected with the results of another cognitive test (the correlation coefficients from 0.24 up to 0.33 ). The results of boys' theoretical technical test had an essential correlative connection with the results of the curriculum test -0.62 , with the terminology test 0.60 , the results of the applied technical test have little correlation coefficient - only 0.39 . The analysis of the data has partially proved the hypothesis that technical knowledge is closely connected with individual's cognitive traits.

The application of the methods of regressive analysis also helps to find statistic relation between diagnostic variables of the research. The Multiple Regressive Analysis has been used in order to find the connection between the test results which show technical sophistication and individual's cognitive personality. The results of the tests showing ev-

Table 2

The correlation coefficients of the results of technical knowledge and cognitive variables

\begin{tabular}{lcc}
\hline Test & Curriculum test & Terminology test \\
\hline The theoretical technical knowledge test & 0.554 & 0.563 \\
The applied technical knowledge test & 0.266 & 0.254
\end{tabular}

Note: Correlation is significant at the 0.01 level (2-tailed). 
ery level of technical knowledge (all population, separately boys' and girls') have been separately analyzed.

\section{Applied Technical Knowledge and Cognitive Personality Traits}

The comparison of the indexes characterizing cognitive personality traits (standardized $\beta$ coefficients and the plains of significance) shows that the results of applied technical test have connection with the results of the basic comprehension-knowledge curriculum tests. From the point of view of the sex aspect it was noticed that the results of the boys' applied technical knowledge test are connected with the results of the curriculum test and are not connected with the terminology test. And the results of the girls' test vice versa have connection between the results of the applied technical knowledge and the terminology and no connection with the curriculum.

In order to define the influence of basic comprehension-knowledge upon technical knowledge, the tasks of the curriculum and terminology tests should be grouped according to dependence to humanitarian or natural sciences blocks. The author of the curriculum test (Blinstrubas, 2002) presented the respondents the facts of two blocks: natural sciences ("Chemistry", "Physics and Astronomy", "Biology", "Mathematics" and "Geography") and humanitarian ("Christianity", "Literature", "Antique Mythology", "Art and Architecture", "History"). The tasks chosen from the terminology test also have connection and associations with natural and humanitarian sciences.

The coefficients show (Table 3) the knowledge of natural sciences positively influences the applied technical knowledge, and the humanities knowledge vice versa has no influence.

Also the connection of the fact blocks and applied technical knowledge from the point of the sex aspect has been defined (see the Tables 4 and 5). The results of the boys' tests are interpreted in the context of all population (the level of natural science knowledge is a little bit higher: standardized coefficient $\beta=0.414$ ), but the results of the girls' applied technical knowledge test did not give statistic results.

The results of the regressive analysis of dependent variable - applied technical knowledge - and non-dependant variable - cognitive personality traits - have proved the hypothesis that individual's cognitive traits are the factor explaining applied knowledge.

Table 3

The significance of the grouped cognitive personality traits upon applied technical knowledge $(N=475)$

\begin{tabular}{|c|c|c|c|}
\hline \multicolumn{4}{|c|}{$\begin{array}{l}\text { Dependent variable: applied technical knowledge } \\
\qquad R=0.341, \text { RSquare }=0.116\end{array}$} \\
\hline Cognitive predictors & Standardized Coefficients $\beta$ & $\mathrm{t}$ & Sig. \\
\hline Basic knowledge (natural sciences) & 0.380 & 4.92 & 0.000 \\
\hline Basic knowledge (the humanities knowledge) & -0.490 & -0.63 & 0.530 \\
\hline
\end{tabular}


Table 4

The influence of the boys' grouped cognitive personality traits upon applied technical knowledge $(N=310)$

\begin{tabular}{lccc}
\hline \multicolumn{4}{c}{ Dependent variable: applied technical knowledge } \\
$R=0.364$, & $R S q u a r e=0.133$ & \\
\hline Cognitive predictors & Standardized Coefficients $\beta$ & $\mathrm{t}$ & Sig. \\
\hline Basic knowledge (natural sciences) & 0.414 & 4.613 & 0.00 \\
Basic knowledge (the humanities knowledge) & -0.064 & -0.716 & 0.474 \\
\hline
\end{tabular}

Table 5

The influence of the girls' grouped cognitive personality traits upon applied technical knowledge $(N=165)$

\begin{tabular}{lcccc}
\hline \multicolumn{3}{c}{ Dependent variable: applied technical knowledge } \\
$R=0.323, R$ Square $=0.104$ & & \\
\hline Cognitive predictors & Standardized Coefficients $\beta$ & \multirow{2}{*}{ t } & \multirow{2}{*}{ Sig. } \\
\hline Basic knowledge (natural sciences) & 0.035 & 0.232 & 0.817 \\
Basic knowledge (the humanities knowledge) & 0.292 & 1.93 & 0.550 \\
\hline
\end{tabular}

The tests of basic comprehension-knowledge influence differently: curriculum knowledge (standardized coefficient $\beta=0.15, p=0.037$ ) and grouped knowledge of natural sciences (standardized coefficient $\beta=0.35, p=0.000$ ) is the stronger factor for the boys; meanwhile, for the girls the terminology knowledge (standardized coefficient $\beta=0.24, p=0.010$ ) is more important factor. According to the dependence to the scientific category, nether natural sciences, nor humanitarian block have any influence upon applied technical knowledge. One can suggest that cognitive personality traits (curriculum or natural science knowledge) influence the complex of applied technical knowledge of technical education.

\section{Theoretical Technical Knowledge Cognitive Personality Traits}

The connection of theoretical technical knowledge and cognitive variables has been studied analogically. Theoretical technical knowledge was described as a dependant variable, and cognitive traits were described as non-dependant variables. At first the whole population was analyzed, and then analogical operations were done separately with the boys and the girls.

The accomplished analysis shows the influence of cognitive variables upon theoretical technical knowledge. The analysis of all respondents' results shows a great influence of non-dependant variables upon theoretical technical knowledge, conversely then upon applied knowledge: $R=0.647, r^{2}=0.419$, standardized $\beta$ coefficients from 0.228 up to 0.446 . 
Table 6

The influence of individual's grouped cognitive traits upon theoretical technical knowledge

\begin{tabular}{|c|c|c|c|}
\hline \multicolumn{4}{|c|}{$\begin{array}{l}\text { Dependent variable: theoretical technical knowledge } \\
\qquad R=0.647, \text { RSquare }=0.419\end{array}$} \\
\hline Cognitive predictors & Standardized Coefficients $\beta$ & $\mathrm{t}$ & Sig. \\
\hline Basic knowledge (natural sciences) & 0.446 & 7.126 & 0.000 \\
\hline Basic knowledge (the humanities knowledge) & 0.228 & 3.643 & 0.000 \\
\hline
\end{tabular}

Table 7

The influence of boys' grouped cognitive traits upon theoretical technical knowledge

\begin{tabular}{lcccc}
\hline \multicolumn{4}{c}{$\begin{array}{c}\text { Dependent variable: theoretical technical knowledge } \\
R=0.695, \text { RSquare }=0.484\end{array}$} & \\
\hline Cognitive predictors & Standardized Coefficients $\beta$ & t & Sig. \\
\hline Basic knowledge (natural sciences) & 0.463 & 6.683 & 0.000 \\
Basic knowledge (the humanities knowledge) & 0.266 & 3.84 & 0.000 \\
\hline
\end{tabular}

Table 8

The influence of girls' grouped cognitive traits upon theoretical technical knowledge

\begin{tabular}{lccc}
\hline \multicolumn{4}{c}{$\begin{array}{c}\text { Dependent variable: theoretical technical knowledge } \\
R=0.561, R S q u a r e\end{array}=0.315$} \\
Cognitive predictors & Standardized Coefficients $\beta$ & t & Sig. \\
\hline Basic knowledge (natural sciences) & 0.327 & 2.470 & 0.015 \\
Basic knowledge (the humanities knowledge) & 0.253 & 1.916 & 0.057 \\
\hline
\end{tabular}

The grouping of basic comprehension-knowledge tasks into natural science and humanitarian blocks is also used in specifying the influence of basic comprehensionknowledge upon technical comprehension test, theoretical technical knowledge. Like in case with applied technical knowledge, at first the whole population was tested, and then separately girls and boys. The results are presented in the Tables 6, 7 and 8 .

The results of the last tables show the high influence, the both set correlation and determination coefficients are very strong: for the general excerption $R=0.647, r^{2}=0.419$, for the boys $R=0.695, r^{2}=0.484$, for the girls $R=0.561, r^{2}=0.315$. Also, the cognitive factors explain the higher percent of theoretical technical knowledge spread $(50 \%$ of boys and $32.7 \%$ of girls). The results of the regressive analysis of dependant variable - the results of theoretical technical knowledge test - and non-dependent variables - cognitive personality traits - have proven that cognitive traits influence greatly the level of theoretical technical knowledge. 
The comparison of applied technical and theoretical technical knowledge results of standardized coefficients $\beta$ standardized by regression, the plane of significance and determination coefficient $r^{2}$ one can conclude that cognitive personality traits influence greatly theoretical technical knowledge rather that applied knowledge.

\section{Conclusions}

It has been established that among the results of the test on applied technical knowledge and results of the two tests on basic comprehension-knowledge (curriculum and terminology) there is an insignificant correlation.

Essential correlation coefficients of theoretical technical knowledge with the results of the tests on basic comprehension-knowledge (curriculum and terminology) have been established. In the boys' group with the aid of regression analysis a considerable relationship between basic comprehension-knowledge in natural sciences and the two tests on comprehension-knowledge in engineering has been established, in the girls' group the influence of the above-mentioned construct reflects only regarding theoretical technical knowledge.

All this leads to maintain that cognitive personality traits make a considerable influence on theoretical technical knowledge, while applied technical knowledge is affected only to some extent.

Following the conclusions it has been established that any teacher could assess the level of technical and basic knowledge and use them as a basis for improving the educational process.

\section{References}

Anastazi, A., Urbina, S. (2001). Психологическое тестирование (in Russian, Psychological Testing). Sankt-Peterburg, Piter.

Bitinas, B. (1998). Ugdymo tyrimu metodologija (in Lithuanian). Vilnius, Jošara.

Blinstrubas, A. (2002). Comprehension-Knowledge of Youth and Young Adults as an Object of Educational Assessment. Summary of doctoral dissertation. Šiauliai University.

Ingekamp, К. (1991). Педагогическая диагностика (in Russian, Pedagogical Diagnostic). Moscow, Pedagogika.

Jovaiša, L., Vaitkevičius, J. (1987). Pedagogikos pagrindai (in Lithuanian). Kaunas, Šviesa.

Kooper, K. (2000). Индивидуальные различия (in Russian, Individual Differences). Moscow, Aspect Press.

Kovieriene, A. (2003). Bendrojo ir techninio išprusimo sąveika (in Lithuanian). Pedagogika, 69, 106-111.

Kovieriene, A. (2004). Comprehension-Knowledge in Engineering of Teenagers and the Youth as an Object of Educational Assessment. Summary of doctoral dissertation. Šiauliai University.

Lienert, G. A. (1958). Mechanisch - Technischer - Verständnistest. Göttingen.

Merkys, G. (1999). Testavimas - socialinių mokslų principas. Metodologinio diskurso projekcija (in Lithuanian). Socialiniai mokslai, 2(19), 7-22.

Motowidlo, S. J., Browniee, A. L., Schmit, M. J. (2008). Effets of Personality characteristics on knowledge, skills, and performance in servicing retail customers. International Journal of Selection and Assessment, 16(3), 272-280. Retrieved on September 12, 2008

http: //papers.ssrn. com/sol3/papers. cfm?abstract_id=1242518 
Sodiya, A. S., Longe, H. O. D., Onashoga, S. A., Awodele, O. (2007). An Improved assessment of personality trairs in software engineering. Interdisciplinary Journal of Information, Knowledge and Managment, 2 Retrieved on September 12, 2008

http: / / ijikm.org/Volume2/IJIKMv2p163-177Sodiya.pdf

A. Kovierienė obtained $\mathrm{PhD}$ degree in social science (educology) from Šiauliai University in 2004 and since then she has been working as associate professor at Mechanics Engineering Department, Šiauliai University. Her main scientific interests are comprehension-knowledge in engineering. 


\section{Lietuvos jaunuoliu kognityviniai bruožai ir techninės žinios}

\section{Ala KOVIERIENĖ}

Tyrimo tikslas - nustatyti techniniu žiniu sąsają su kognityviniais ir nekognityviniais veiksniais, statistiškai apdoroti duomenis, panaudojant modernius daugiamatès statistikos metodus. Straipsnyje pateikti tyrimų rezultatai, kurie rodo sąsają tarp techninių žinių ir kognityviniu gebejjimu.

Nustatyta, kad vaikinų ir merginų taikomujų techninių žinių rezultatai mažai susiję su kitu kognityviniu testų rezultatais. Vaikinų teoriniu techninių žinių testo rezultatai turi esminị koreliacinị ryšį su kitais testais, išskyrus taikomujų techninių žinių testo rezultatus. Merginų taikomujų techninių žinių testo rezultatai su teorinių techninių žinių testo rezultatais menkai susiję.

Apibendrinant visas šiame straipsnyje pateiktas išvadas galima teigti, kad asmenybès kognityvinès savybės turi ryškių sąsajų su teorinèmis techninėmis žiniomis, mažiau - su taikomosiomis techninėmis žiniomis. Pateiktos išvados atveria galimybę kiekvienam pedagogui įvertinus techninio ir bendrojo išprusimo lygị ir tuo remiantis koreguoti ugdymo procesą. 